\title{
LABORATORY STUDIES TO DETERMINE THE EFFICACY OF SELECTED INSECTICIDES ON TOMATO/POTATO PSYLLID
}

\author{
N.A. BERRY, M.K. WALKER and R.C. BUTLER \\ Plant \& Food Research, Private Bag 4704, Christchurch 8140, \\ New Zealand
}

Corresponding author: BerryN@crop.cri.nz

\begin{abstract}
Tomato/potato psyllid (Bactericera cockerelli) was first recorded in New Zealand in 2006, and is now a significant pest of solanaceous crops in both glasshouses and fields. Given the potential impact of this insect and its associated pathogen(s) on crop yields, immediate control options are required. Thirteen insecticides were selected for testing. In laboratory bioassays, insecticides were applied at recommended field rates as a spray (12 chemicals) or a seedling drench ( 1 chemical). The recorded mortality of tomato/potato psyllid nymphs $48 \mathrm{~h}$ after spraying with dichlorvos, lambda-cyhalothrin, methomyl, taufluvalinate, methamidophos and abamectin was 98-100\%. After $168 \mathrm{~h}$, applications of azadirachtin, spiromesifen, abamectin, spirotetramat and thiacloprid gave $82-100 \%$ mortality, while buprofezin, pymetrozine and imidacloprid drench gave 36-53\% mortality of nymphs. Further tests are required to confirm the efficacy under cropping conditions. Keywords: tomato/potato psyllid, pest, laboratory bioassays, insecticides, New Zealand.
\end{abstract}

\section{INTRODUCTION}

The arrival of the tomato/potato psyllid (Bactericera cockerelli (Sulc), (Hemiptera, Triozidae) (TPP) in New Zealand (Teulon et al. 2009), and the recent identification of its role as a vector of the bacterial pathogen Liberibacter (Munyaneza et al. 2007), has presented a considerable challenge to the New Zealand greenhouse vegetable, tomato and potato industries. TPP causes crop damage through direct feeding, and Liberibacter is believed to cause the disease 'zebra chip' of potatoes. TPP is also believed to be associated with 'psyllid yellows' in tomatoes and potatoes, although the exact relationship is unknown (Teulon et al. 2009).

In New Zealand greenhouses, Integrated Pest Management (IPM) programmes are based on biological control and pollination requirements (Martin 2008; Zonda Resources Ltd 2009). IPM practices have been developed and implemented in New Zealand outdoor tomatoes since 1990 (Cameron et al. 2009). These practices have been correlated with effective biological control and a reduction in the number and type of insecticides applied (Cameron et al. 2009). Producers of potatoes in New Zealand use insecticides to control potato tuber moth (Phthorimaea operculella) and several species of virus transmitting aphids, e.g. Myzus persicae (van Toor \& Teulon 2006). Insecticide resistance management strategies have been developed for these potato insects, due to their confirmed resistance to some organophosphate, carbamate and pyrethroid insecticides (Martin et al. 2005; van Toor \& Teulon 2006; Anon. 2008). An insecticide resistance management strategy was also developed for outdoor tomatoes due to increasing control failures of Helicoverpa armigera when pyrethroids were used (Cameron et al. 2009).

The recent arrival of TPP threatens the use of IPM practices in potato, tomato and greenhouse crops. For greenhouse crops, there are no biological control agents, or 
IPM-compatible insecticides registered for control of TPP. For tomato and potato crops, resistance management strategies for key insect pests are threatened by a lack of registered insecticides for the control of TPP.

Given this potential impact IPM-compatible control options were required immediately. In this study, laboratory bioassays were carried out to determine the efficacy of 13 insecticides on TPP. Insecticides were selected based on their current registration in New Zealand, their reported efficacy in overseas studies (van Toor et al. 2008) and their compatibility with current IPM programmes in New Zealand.

\section{Insect rearing}

\section{MATERIALS AND METHODS}

TPP nymphs for testing were obtained from a laboratory colony at Plant \& Food Research, Mt Albert, Auckland, established from adults collected from greenhouse tomatoes, Auckland. TPP were reared on plants of tomato (cv. 'Moneymaker') or capsicum (cv. 'Giant Bell') in a controlled temperature room at $23^{\circ} \mathrm{C}$ and $60 \% \mathrm{RH}$, under 16:8 h light:dark.

\section{Insecticide treatments}

Thirteen insecticides were each tested at their recommended field rate (Table 1).

\section{TABLE 1: Insecticide treatments used in the bioassays.}

\begin{tabular}{|c|c|c|c|c|}
\hline Active ingredient & Registered use & Chemical group & Formulation & $\begin{array}{l}\text { Field rate } \\
\text { (ai) }\end{array}$ \\
\hline dichlorvos & $\begin{array}{c}\text { Greenhouse } \\
\text { crops, vegetables }\end{array}$ & Organophosphate & $\begin{array}{c}1000 \mathrm{~g} / \text { litre } \\
\mathrm{EC}\end{array}$ & $350 \mathrm{~g} / \mathrm{ha}$ \\
\hline lambda-cyhalothrin & $\begin{array}{l}\text { Tomato, } \\
\text { potato }\end{array}$ & Pyrethroid & $\begin{array}{l}250 \mathrm{~g} / \text { litre } \\
\mathrm{CS}\end{array}$ & $10 \mathrm{~g} / \mathrm{ha}$ \\
\hline methomyl & $\begin{array}{l}\text { Tomato, } \\
\text { capsicum }\end{array}$ & Carbamate & $\begin{array}{l}200 \mathrm{~g} / \text { litre } \\
\text { SC }\end{array}$ & $400 \mathrm{~g} / \mathrm{ha}$ \\
\hline taufluvalinate & Tomato & Pyrethroid & $\begin{array}{l}240 \mathrm{~g} / \text { litre } \\
\text { SC }\end{array}$ & $72 \mathrm{~g} / \mathrm{ha}$ \\
\hline methamidophos & $\begin{array}{l}\text { Tomato, } \\
\text { potato }\end{array}$ & Organophosphate & $\begin{array}{l}600 \mathrm{~g} / \text { litre } \\
\text { SC }\end{array}$ & $480 \mathrm{~g} / \mathrm{ha}$ \\
\hline azadirachtin & $\begin{array}{l}\text { Greenhouse } \\
\text { crops, potato }\end{array}$ & Tetranortriterpenoid & $10 \mathrm{~g} /$ litre EC & $30 \mathrm{~g} / \mathrm{ha}$ \\
\hline buprofezin & $\begin{array}{l}\text { Tomato, } \\
\text { capsicum }\end{array}$ & Thiadiazine & $\begin{array}{l}440 \mathrm{~g} / \text { litre } \\
\text { SC }\end{array}$ & $132 \mathrm{~g} / \mathrm{ha}$ \\
\hline spiromesifen & $\begin{array}{l}\text { Tomato, } \\
\text { capsicum }\end{array}$ & $\begin{array}{l}\text { Tetronic acid } \\
\text { derivatives }\end{array}$ & $\begin{array}{l}240 \mathrm{~g} / \text { litre } \\
\text { SC }\end{array}$ & $144 \mathrm{~g} / \mathrm{ha}$ \\
\hline pymetrozine & Tomato & Pyridine azomethine & $\begin{array}{l}500 \mathrm{~g} / \mathrm{kg} \\
\text { WDG }\end{array}$ & $200 \mathrm{~g} / \mathrm{ha}$ \\
\hline abamectin & Tomato & Avermetin & $18 \mathrm{~g} /$ litre EC & $8.1 \mathrm{~g} / \mathrm{ha}$ \\
\hline spirotetramat & Kiwifruit & Ketoenols & $\begin{array}{l}240 \mathrm{~g} / \text { litre } \\
\text { SC }\end{array}$ & $96 \mathrm{~g} / \mathrm{ha}$ \\
\hline imidacloprid & $\begin{array}{l}\text { Onions, vegetable } \\
\text { brassicas, lettuce }\end{array}$ & Neonicotinoid & $\begin{array}{l}350 \mathrm{~g} / \text { litre } \\
\text { SC }\end{array}$ & $\begin{array}{c}7 \mathrm{~g} / 2.5 \text { litres } \\
\text { wtr/1000 } \\
\text { plants }\end{array}$ \\
\hline thiacloprid & $\begin{array}{l}\text { Apples, avocados, } \\
\text { kiwifruit, } \\
\text { nectarines, peaches }\end{array}$ & Neonicotinoid & $\begin{array}{l}480 \mathrm{~g} / \mathrm{litre} \\
\mathrm{SC}\end{array}$ & $288 \mathrm{~g} / \mathrm{ha}$ \\
\hline
\end{tabular}




\section{Application of insecticides}

Dichlorvos, lambda-cyhalothrin, methomyl, taufluvalinate, methamidophos, azadirachtin, buprofezin, spiromesifen, pymetrozine, abamectin, spirotetramat and thiacloprid were applied as direct sprays.

One leaf disc (50 mm diameter) taken from a capsicum (cv. 'Cupra') plant was embedded in $1 \%$ agar in a Petri dish (55 $\mathrm{mm}$ diameter, $11 \mathrm{~mm}$ high). The agar was used to minimise wilting of the leaf disc and restrict psyllids to the sprayed leaf surface. Ten $3-4^{\text {th }}$ instar nymphs were placed on the leaf disc in each Petri dish using a fine paintbrush, and the dishes were stored in a refrigerator at $4{ }^{\circ} \mathrm{C}$ overnight.

Five replicate dishes were used for each insecticide tested, along with three control (water spray) dishes for each insecticide. On every spray day, there were five untreated (no spray) dishes; two or three insecticides were applied per spray day.

Each Petri dish was taken from the refrigerator, opened and immediately sprayed using a Burkard computer-controlled sprayer (Burkard Manufacturing Co Ltd, Hertfordshire, England) at $50 \mathrm{kPa}$. The sprayer nozzle delivered droplets with a medium diameter of $18 \mu \mathrm{m}$ and each insecticide treatment was applied in $0.1 \mathrm{ml}$ of water treated by reverse osmosis to a Petri dish, equivalent to a spray application rate of 420 litres/ha. The top surface of the leaf disc was sprayed, as psyllids only had access to this surface. For practical reasons dishes were sprayed in a systematic sequence, with one dish sprayed at a time. For each chemical, three control dishes were sprayed with water, then five dishes were sprayed at $100 \%$ field rate. The machine was cleaned between chemical applications.

Imidacloprid was applied as recommended using a drench application to seedlings (Anon. 2009a). A cell tray with 105 capsicum seedlings (cv. 'Giant Bell') grown from seed in the glasshouse (Plant \& Food Research, Lincoln, Canterbury) was used. Fifteen seedlings (1 row of the tray) were treated with insecticide, with a water control or formed the untreated control in each tray, with a buffer row before and between each of the treatment rows. At the 3-true leaf stage, $2.5 \mathrm{ml}$ of insecticide solution was applied to the growing medium of each transplant using a pipette in two amounts of $1.25 \mathrm{ml}$. No solution was observed draining from the cell trays. Treated seedlings were then placed in a controlled temperature room $\left(18-20^{\circ} \mathrm{C}, 60 \% \mathrm{RH}\right.$ and $16: 8 \mathrm{~h}$ light:dark) for $48 \mathrm{~h}$ to allow absorption of the insecticide through their roots. Five leaves (of similar size) were randomly selected from the 15 seedlings in each treatment. Leaves were embedded in $1 \%$ agar in Petri dishes and $103-4^{\text {th }}$ instar psyllid nymphs were added to each dish as described above. Five dishes were used per insecticide, along with three control dishes (water spray) and five dishes were left untreated (no spray).

\section{Assessment of mortality}

All Petri dishes were kept in controlled temperature rooms at $18^{\circ} \mathrm{C}, 60 \% \mathrm{RH}$ and 16:8 h light:dark. Numbers of live and dead psyllid nymphs were assessed every $24 \mathrm{~h}$ up to $48 \mathrm{~h}$ or $168 \mathrm{~h}$. A psyllid nymph was recorded as dead if it did not move one body length when lightly prodded with a fine paintbrush. Different brushes were used for each insecticide and then discarded.

\section{Statistical analyses}

Mortality of psyllids at the final assessment time was analysed using a binomial generalised model with a logit link (McCullagh \& Nelder 1989). Contrasts were used within the analysis to compare the various treatments, i.e. untreated with control (water), test chemicals with each other. As there was no evidence of over-dispersion, chi-squared tests were used in the analyses of deviance to assess these contrasts. Results are presented as percentage mortality with $95 \%$ confidence limits (calculated on the transformed logit scale and back-transformed to percentages). Changes in percentage mortality of psyllids over time were explored graphically and with simple summary statistics. In graphs showing changes over time, percentage mortality for a particular chemical was calculated as $100 *$ (total mortality in all dishes)/(total number of psyllids in all dishes). 


\section{Mortality at final assessment}

\section{RESULTS}

Field rate applications of dichlorvos, lambda-cyhalothrin, methomyl, taufluvalinate and methamidophos caused 98-100\% mortality of TPP after $48 \mathrm{~h}$ (Table 2). Field rate applications of azadirachtin, spiromesifen, abamectin, spirotetramat and thiacloprid gave $82-100 \%$ mortality of TPP after $168 \mathrm{~h}$, while buprofezin, pymetrozine and imidacloprid gave $36-53 \%$ mortality after $168 \mathrm{~h}$ (Table 2). Percentage mortality of TPP did not vary significantly between the untreated (no spray) and control (water) treatments at either $48 \mathrm{~h}(\mathrm{P}=0.69)$ or $168 \mathrm{~h}(\mathrm{P}=0.54)$ (Table 2$)$.

TABLE 2: Mortality (\%) of tomato/potato psyllid nymphs at the final assessment times, 48 or $168 \mathrm{~h}$ after spraying. Values in parentheses are the $\mathbf{9 5 \%}$ confidence limits.

\begin{tabular}{lcc}
\hline Chemical & $48 \mathrm{~h}$ & $168 \mathrm{~h}$ \\
\hline Untreated $^{1}$ & $4.0(1.5-10.2)$ & $11.2(7.4-16.5)$ \\
Control $^{1}$ & $5.0(2.6-9.4)$ & $13.0(9.7-17.4)$ \\
dichlorvos & $100.0(92.9-100.0)$ & \\
lambda-cyhalothrin & $100.0(92.6-100.0)$ & \\
methomyl & $97.9(86.6-99.7)$ & \\
taufluvalinate & $98.0(87.1-99.7)$ & \\
methamidophos & $98.0(87.1-99.7)$ & \\
azadirachtin & & $100.0(92.9-100.0)$ \\
buprofezin & & $44.9(31.7-58.9)$ \\
spiromesifen & & $81.6(68.3-90.2)$ \\
pymetrozine & & $36.0(24.0-50.1)$ \\
abamectin & & $100.0(92.9-100.0)$ \\
imidacloprid & & $53.1(39.2-66.5)$ \\
thiacloprid & & $100.0(92.7-100.0)$ \\
spirotetramat & & $96.0(85.4-99.0)$ \\
\hline
\end{tabular}

${ }^{1}$ Untreated and control data averaged over all spray days.

\section{Mortality over time}

The mortality of TPP for dishes sprayed with field rate applications of pymetrozine, abamectin, thiacloprid, spirotetramat, imidacloprid, azadirachtin, buprofezin and spiromesifen over $168 \mathrm{~h}$ is shown in Figure 1 (insecticides grouped by spray day), together with data from control dishes (water and untreated) sprayed on the same days as these chemicals. The mortality of TPP in untreated and water controls was similar at single assessment events and between application days. Bioassays showed three different time-response patterns. The patterns of changes in mortality over $168 \mathrm{~h}$ for field rate applications of abamectin, azadirachtin and thiacloprid resulted in $100 \%$, $96 \%$ and $88 \%$ mortality of TPP respectively after only $48 \mathrm{~h}$ (Fig. 1). Mortality of TPP for field rate applications of spiromesifen and spirotetramat was only $6 \%$ and $4 \%$ after $24 \mathrm{~h}$, rising steadily to $33 \%$ and $34 \%$ respectively by $72 \mathrm{~h}$, and to $82 \%$ and $96 \%$ by the final assessment (168 h) (Fig. 1). Changes in mortality over $168 \mathrm{~h}$ for field rate applications of pymetrozine, imidacloprid and buprofezin resulted in 26\%, $14 \%$ and $14 \%$ mortality respectively after $72 \mathrm{~h}$ and $36 \%, 53 \%$ and $45 \%$ mortality respectively at the final assessment (168 h) (Fig. 1). 


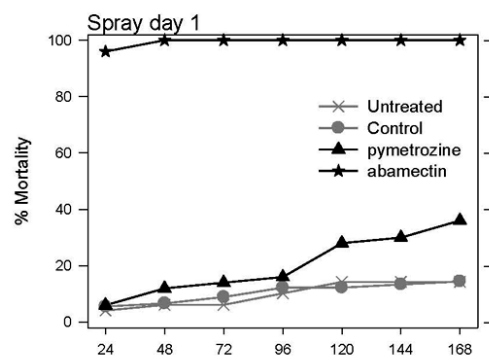

Spray day 3
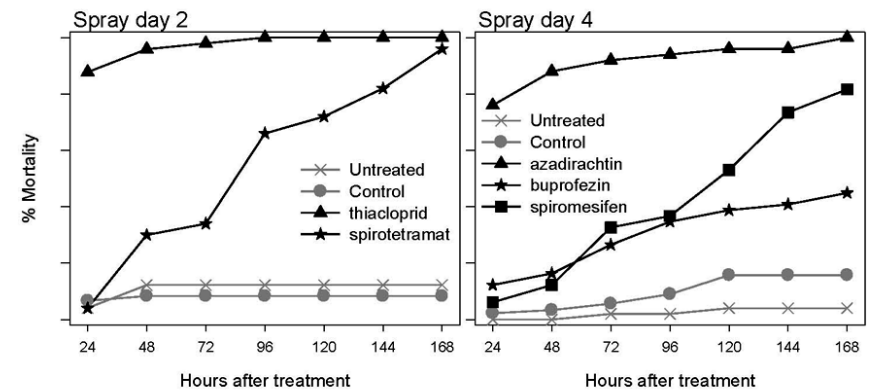

FIGURE 1: Mortality (\%) at each assessment time for pymetrozine and abamectin (Spray day 1), thiacloprid and spirotetramat (Spray day 2), imidacloprid (Spray day 3) and azadirachtin, buprofezin and spiromesifem (Spray day 4), which were all applied at field rate. Data for controls and untreated dishes are from the same spray day as when the chemical/s were applied.

\section{DISCUSSION}

The contact insecticides dichlorvos, lambda-cyhalothrin, methomyl, taufluvalinate and methamidophos have a direct effect on the stomach and/or nervous system of the target insect (Anon. 2009a). In the present study, these insecticides gave 98-100\% mortality of TPP nymphs after $48 \mathrm{~h}$. Despite the high mortality rates that may be achieved with these insecticides, in general they also kill natural enemies jeopardising biological control (Anon. 2009b; Dent 1995), and so need to be used cautiously in order to meet current resistance management strategies. For example, in potatoes increased use of organophosphate, carbamate and pyrethroid insecticides to control TPP may increase resistance selection pressure against the potato tuber moth and aphid pests (Martin et al. 2005; van Toor \& Teulon 2006; Anon. 2008).

North American studies have identified two biotypes of TPP, native and invasive (Liu et al. 2006), and have reported that the invasive biotype is less susceptible to some insecticides than the native biotype (Liu \& Trumble 2007). In New Zealand, preliminary analysis of psyllid DNA sequences indicates there may be more than one biotype present (I.A.W. Scott, Plant \& Food Research, pers. comm.) therefore differences in response to insecticide applications may occur.

The success of IPM programmes in greenhouse and outdoor vegetable crops often requires the use of selective chemicals that allow naturally occurring and introduced biological control agents to survive. In New Zealand tomatoes, for example, the establishment of effective parasitoids for the control of Helicoverpa armigera and the use of new insecticide classes with low toxicity profiles have contributed to a $95 \%$ decline in insecticide use over the last 20 years (Cameron et al. 2009). Pymetrozine and buprofezin are slower-acting insecticides and are reported to be relatively harmless to biological 
control agents and bumble bees (Anon. 2009a). Studies by Liu \& Trumble (2005) showed pymetrozine was effective against TPP in greenhouse tomatoes. Buprofezin has not been trialled against TPP in the USA, but it is used for the control of citrus psyllids (Pena et al. 1999). In the present study, laboratory bioassays using buprofezin and pymetrozine showed only $45 \%$ and $36 \%$ mortality of TPP after $168 \mathrm{~h}$ (Table 2, Fig. 1). Buprofezin inhibits the moulting process of immature stages of the pest (Anon. 2009a). Pest mortality is expected to be affected over a number of generations and laboratory bioassays of the type used in the present study may not accurately determine the effectiveness of buprofezin. Pymetrozine has translaminar and systemic activity and inhibits pest feeding. Pests may survive for a few days after application, but without causing plant damage (Anon. 2009a).

Imidacloprid is a systemic insecticide with stomach and contact action, which is relatively harmless to natural enemies if applied using a seedling drench. However, it is toxic to honeybees. Imidacloprid has been effectively used in tomato crops in California (Trumble 2006) and as a soil treatment for potatoes (Cranshaw \& Hein 2004, in van Toor $\&$ Teulon 2006). The present laboratory bioassays showed only $53 \%$ mortality of TPP after $168 \mathrm{~h}$ (Table 2, Fig. 1), with increasing nymph mortality over time. As mentioned, studies by Liu \& Trumble (2007) have shown that the TPP invasive biotype is more tolerant of or resistant to imidacloprid than the native biotype.

Azadirachtin, spiromesifen, abamectin, spirotetramat and thiacloprid are sloweracting insecticides and cause a variety of effects including paralysis and inhibition of metabolic processes, feeding and moulting (Anon. 2009a). In the present study these insecticides caused $82-100 \%$ mortality of TPP after $168 \mathrm{~h}$ (Table 2). Three of these insecticides (azadirachtin, spiromesifin and spirotetramat) are reported to demonstrate useful selectivity towards biological control agents and bees (Anon. 2009a; van Toor et al. 2008) and may be compatible with existing IPM programmes. Spirotetramat interferes with lipid synthesis, is active through ingestion, and is translocated within the phloem and vascular tissue of the plant (Anon. 2009c). Spiromesifen is a non-systemic inhibitor of lipid synthesis and has been reported to effectively control TPP in tomato, capsicum and potato crops (Elbert et al. 2005). Azadirachtin is a slow-acting, naturally based, antifeeding insecticide. Application recommendations emphasise early season use, to promote feeding inhibition, early moulting and a reduction in fecundity (Anon. 2009a).

Laboratory bioassays measure pest mortality over fixed periods, and may not accurately reflect the action of insecticides that reduce feeding or interfere with pest populations over longer intervals. Field tests are therefore required to determine the efficacy of the above IPM compatible insecticides under cropping conditions. Further tests are also essential to determine whether discrete populations of TPP respond differently to these insecticides in various host crops or under a range of conditions.

\section{ACKNOWLEDGEMENTS}

We thank the editor of NZPP for allowing prior publication of some of the data in this manuscript in a non-peer-reviewed industry magazine, due to the urgent need for the information to be disseminated as quickly and widely as possible given the threat of the potato/tomato psyllid to several important horticultural crops. We thank the various chemical companies for supplying samples of insecticides for testing. Thanks to Dominic Hartnett, Plant \& Food Research, Auckland, for supply of TPP. We also thank those industry representatives who provided comment on the final list of insecticides. Thanks also to Bruce Chapman, Insect Science Ltd, for his valuable comments on the draft manuscript and Daniel Park, Plant \& Food Research, for scientific editing. This research was funded by the New Zealand Foundation for Research, Science and Technology and The New Zealand Institute for Plant \& Food Research Limited.

\section{REFERENCES}

Anon. 2008. Managing insect pests and minimising insecticide resistance in potatoes: An Interim Strategy. Potatoes New Zealand, Horticulture New Zealand, Wellington, New Zealand. 
Anon. 2009a. New Zealand Novachem Agrichemical Manual. AgriMedia Ltd, Ashcroft House, Christchurch, New Zealand. 779 p.

Anon. 2009b. Koppert Biological Systems Ltd. Side-effects. http://side-effects.koppert. $\mathrm{nl} / \#$ (accessed 27 May 2009).

Anon. 2009c. Evaluation of the new active spirotetramat in the product Movento 240 SC insecticide. 57 p. Australian Pesticides and Veterinary Medicines Authority. Canberra, Australia. www.apvma.gov.au/publications/download/prs_spirotetramat. pdf (accessed 27 May 2009).

Cameron PJ, Walker GP, Hodson AJ, Kale AJ, Herman TJB 2009. Trends in IPM and insecticide use in processing tomatoes in New Zealand. Crop Protection 28: 421-427.

Cranshaw SW, Hein GL 2004. Potato XXII; Potato Psyllid. http://highplainsipm.org/ HpIPMSearch/Docs/potatopsyllid-potato.htm (last updated 4 December 2004, accessed 21 February 2007).

Dent D ed. 1995. Integrated Pest Management. Chapman and Hall, London. 356 p.

Elbert A, Bruck E, Melgarejo J, Schnorbach HJ, Sone S 2005. Field development of Oberon ${ }^{\circledR}$ for whitefly and mite control in vegetables, cotton, corn, strawberries, ornamentals and tea. Pflanzenschutz-Nachrichten Bayer 58(3): 441-468.

Liu DG, Trumble JT 2005. Interactions of plant resistance and insecticides on the development and survival of Bactericera cockerelli [Sulc] (Homoptera: Psyllidae). Crop Protection 24(2): 111-117.

Liu DG, Trumble JT, Stouthamer R 2006. Molecular characterisation indicates recent introductions of potato psyllid (Bactericera cockerelli) into western North American are genetically different from eastern populations. Entomologia Experimentalis et Applicata 118: 177-183.

Liu DG, Trumble JT 2007. Comparative fitness of invasive and native populations of the potato psyllid (Bactericera cockerelli). Entomologia Experimentalis et Applicata 123(1): 35-42.

Martin NA, 2008. History of biocontrol in the protected cropping industry in Australia and New Zealand. Proceedings of the Australia and New Zealand Biocontrol Conference 2008, 10-14 February, Sydney, Australia. p. 51 (Abstract only).

Martin NA, Beresford RM, Harrington KC 2005. Pesticide Resistance: Prevention and Management Strategies 2005. New Zealand Plant Protection Society, Hastings, New Zealand. 225 p.

McCullagh P, Nelder JA 1989. Generalized Linear Models. Chapman \& Hall, London.

Munyaneza JE, Crosslin JM, Upton JE 2007. Association of Bactericera cockerelli (Homoptera: Psyllidae) with "Zebra Chip," a new potato disease in southwestern United States and Mexico. Journal of Economic Entomology 100(3): 656-663.

Pena JE, Duncan R, Klema E, Hunsberger A 1999. Evaluation of direct and indirect action of insecticides and acaricides for control of lime and avocado pests. Proceedings of the Florida State Horticultural Society 112: 213-217.

Teulon DAJ, Workman PJ, Thomas KL, Nielsen M-C 2009. Bactericera cockerelli: Incursion, dispersal and current distribution on vegetable crops in New Zealand. New Zealand Plant Protection 62: 136-144.

Trumble JT 2006. The Tomato Psyllid: A new problem on tomatoes in California and Baja Mexico. http://ceventura.ucdavis.edu/Vegetable Crops/Tomato Psyllid.htm (last accessed 20 April 2009).

van Toor, RF, Teulon, DAJ 2006. Insecticide practice for aphid control in potatoes. New Zealand Plant Protection 59: 235-241.

van Toor RF, Martin N, Teulon DAJ 2008. Tomato/potato psyllid in New Zealand: immediate and future options for control with insecticides in covered crops - revised August 2008. Crop \& Food Research Confidential Report No 2223. New Zealand Institute for Crop \& Food Research Limited, Christchurch, New Zealand. 28 p.

Zonda Resources Ltd 2009. Bumble bees and biological control. www.zonda.net.nz/ biocontrol.asp (accessed 27 May 2009). 